\title{
Gallbladder Cancer pT4 TNM Finding v8
}

National Cancer Institute

\section{Source}

National Cancer Institute. Gallbladder Cancer pT 4 TNM Finding v8. NCI Thesaurus. Code C134654.

Gallbladder cancer with tumor invading the main portal vein or hepatic artery or invading two or more extrahepatic organs or structures. (from AJCC 8th Ed.) 